\title{
Developing Collegiate Student Proclivities to Entrepreneurial Leadership
}

\author{
Matthew M. Mars \\ Assistant Professor \\ Leadership and Innovation \\ University of Arizona \\ Robert M. Torres \\ Professor \\ Agricultural Education \\ University of Arizona
}

\begin{abstract}
Individuals with skills specific to innovation and entrepreneurial strategy are in high demand within the contemporary workforce. This demand transcends most, if not all, professions and career paths. Yet, entrepreneurial leadership education continues to be viewed mostly as a business-oriented domain. We expand the otherwise narrow scope of entrepreneurial leadership education through an examination of the effects of an interdisciplinary, project-based entrepreneurial leadership course on student proclivities to leading change. We used a retrospective pre- and post-measure pre-experimental design to conduct the study. Our findings indicate an increase across the sample $(n=62)$ in entrepreneurial leadership proclivity following course completion. The insights we generate reveal opportunities for strengthening collegiate entrepreneurial leadership curriculum and instruction and enhancing the capacities of students to become effective leaders of change (i.e., change agents).
\end{abstract}

\section{Introduction}

The unmet need for leaders who are capable of introducing, facilitating, and sustaining impactful change is pervasive and cuts across a diverse range of community, economic, and organizational contexts (Borasi \& Finnigan, 2010; Maton, 2008; Westover, 2010). This pervasiveness is the result of the rapid and ongoing emergence and evolution of community, economic, political, social, and technological conditions and phenomena. Consequently, the initiation and implementation of new cross-disciplinary leadership curricula that prepare collegiate students to be innovators and leaders of change (i.e., change agents) is imperative (Davey, Hannon, \& Penaluna, 2016; Hackman, Olive, Guzman, \& Burman, 1999; Paxton \& Van Stralen, 2015).

\section{Literature Review}

The rapid creation and diffusion of innovation is the primary thrust of the now dominant knowledge economy (Powell \& Snellman, 2004). Accordingly, individuals with the knowledge and skills to rapidly and effectively advance innovations via entrepreneurial strategy are in high demand (Boyles, 2012; Paxton \& Van Stralen, 2015). This demand extends beyond private 
industry to include educational, governmental, and public settings (Wagner, 2012). The preceding workforce demand has made innovation and entrepreneurship curricula one of the fastest growing domains in higher education (Duval-Couetil, 2013; Katz, 2003; Kuratko, 2005).

The primary focus of collegiate entrepreneurship and innovation curricula is on business contexts and the commercial application of innovations (Tracey \& Phillips, 2007). While commercial entrepreneurs aim to generate and capture financial wealth by exploiting market opportunities, social entrepreneurs aspire to create diverse impacts by countering market and government failures via disruptive solutions and models (Austin, Stevenson, \& Wei-Skillern, 2006; Santos, 2012). Consequently, there is also notable growth in the development and delivery of collegiate-level curricula specific to social entrepreneurship and innovation (Pache \& Chowdhury, 2012; Mars \& Rhoades, 2012; Miller, Wesley, \& Williams, 2012). The diversity of collegiate curricula also spans organizational-types to include the application of entrepreneurial leadership strategies within both emergent and established organizations (Heinonen \& Poikkijoki, 2006). Yet, there is limited research that examines the impact of collegiate entrepreneurship and innovation instruction on the perspectives and orientations (i.e., proclivities) of students to the leadership of change.

The ability to teach individuals to be entrepreneurial has been a topic of considerable debate (Henry, Hill, \& Leitch, 2005; Martin, McNally, \& Kay, 2013; Sanchez, 2013). On one hand, some scholars purport that the effectiveness of entrepreneurship education in enhancing student intentions and capacities to engage in innovation and entrepreneurial activities remain uncertain (Bae, Qian, Miao, \& Fiet, 2014; Oosterbeek, van Praag, \& Ijsselstein, 2010). On the other hand, there is also a substantial body of research that indicates entrepreneurship education is effective in preparing and motivating students to be both innovative and entrepreneurial (e.g., DeTienne \& Chandler, 2004; Kuratko, 2005; Pittaway \& Cope, 2007). In the current study, we contribute to this debate through an examination of the effects of a project-based entrepreneurial leadership course (ELC) on the leadership proclivities of college students with a diverse range academic backgrounds and professional interests. In doing so, we introduce entrepreneurial leadership as a cross-disciplinary domain within the broader pantheon of leadership education with specific emphasis being placed on the preparation of students to serve as leaders of change (i.e., change agents).

\section{Theoretical Framework}

Entrepreneurial leadership is a relatively nascent concept that remains mostly undefined (Leitch \& Volery, 2017). Early conceptual work has described entrepreneurial leaders as those who set up organizations to be flexible structures that are able to exploit the opportunities that consistently emerge from the ever-changing environments that characterize the $21^{\text {st }}$ century knowledge economy (Gupta, MacMillan, \& Surie, 2004; McGrath \& MacMillan, 2000; Powell \& Snellman, 2004; Surie \& Ashley, 2008). This body of work has primarily linked the notion of entrepreneurial leadership with business strategy and new venture development (e.g., Cogliser \& Brigham, 2004; Fernald, Solomon, \& Tarabishy, 2005; Leitch, McMullen, \& Harrison, 2013; Vecchio, 2003). Theoretical connections have also been made between transformational leadership and entrepreneurial leadership. Transformational leadership is generally theorized to be inwardly focused on the transformation of organizations via the empowerment of the member 
actors (Eisenbach, Watson, \& Pillai, 1999; Herold, Fedor, \& Cladwell, 2008; Lamm, et al., 2016; MacKenzie, Podsakoff, \& Rich, 2001). Additionally, entrepreneurial leadership has been framed as a specialized leadership style with leaders elevating organizational performance through the application of high levels of creativity, vision, and motivational capacities (Engelen, Gupta, Strenger, \& Brettel, 2015; Gumusluoglu \& Ilsev, 2009; Gupta, et al., 2004).

In this study, we expand the conceptual parameters of the preceding body of scholarship by holistically defining entrepreneurial leadership as the strategic process for identifying and understanding opportunities for change within and across organizational environments, formulating innovative models for acting on such opportunities, and mobilizing and allocating the resources needed to advance and sustain the targeted change. More succinctly, entrepreneurial leadership is understood to be the advancement of innovation and change through the application of entrepreneurial strategy. This definition emphasizes the intent of creating meaningful change within and beyond the boundaries of organizations and recognizes the relevancy of entrepreneurial leadership to all organizational environments and societal sectors (i.e., communities, economies, governments, industry, public organizations). Consistent with this definition, we conceptualize entrepreneurial leaders as change agents who advance commercial and/or social innovation by way of entrepreneurial strategy.

Returning to the leadership education domain, entrepreneurial leadership as a distinct instructional topic and programmatic area of study remains underdeveloped. In fact, the term "entrepreneurial leadership education" has mostly been used synonymously with conventional entrepreneurship education (i.e., new business development methodologies and strategies) and has rarely been included as a topical area within general leadership curricula and textbooks (Okudan \& Rzasa, 2006). While diverse in perspective, existing studies specific to entrepreneurial leadership education remain firmly rooted in the business and management contexts (e.g., Bagheri \& Pihie, 2011; Clarke, Thorpe, Anderson, \& Gold, 2006; Kuratko, 2007). We expand the scope of entrepreneurial leadership education beyond the narrow contexts of new business venture creation and organizational development through an examination of the effects of an interdisciplinary, project-based ELC on student proclivities to leading change within and across multiple contexts and settings (e.g., community coalitions, government agencies, public organizations, private firms).

Entrepreneurial leadership proclivity indicates the orientation and perspective of an individual to opportunities for innovation and entrepreneurship (Griffith, Noble, \& Chen, 2006; Matsuno, Mentzer, \& Ozsomer, 2002). Entrepreneurial learning and knowledge acquisition have been directly linked to increases in such proclivity (Zhao, Seibert, \& Hill, 2005; Zhou, 2007; Zhou, Barnes, \& Lu, 2010). It remains unclear if this linkage extends to the influence of entrepreneurial leadership education on student dispositions and orientations for leading change, regardless of context and setting, through innovation and entrepreneurial strategy.

Innovation is the creation of monetary value and/or non-monetary impact through the development and implementation of solutions that are both novel and viable (culturally, economically, environmentally, politically, socially) (Baumol, 2004, 2010). At the most fundamental level, innovation is an idea-driven process that occurs in direct response to a vision of future possibilities (Chen, 2007; Gupta, et al., 2004). The generation of innovative ideas 
involves the creative blending of diverse perspectives and experiences, as well as adaption to unexpected challenges and opportunities (Kickul, Gundry, Barbosa, \& Whitcanack, 2009). Innovation also demands both rigorous forethought and strategic intuition by those who seek to lead in its initiation and implementation (Kickul, et al., 2009; Miller \& Ireland, 2005).

Entrepreneurial strategy involves a sequence of choices and steps that enable leaders to rigorously analyze and methodically act on opportunities to advance innovation (Shane, 2003). Such strategy relies heavily on data analysis to guide well-informed decisions that mitigate known risks and promote the tolerance of unknown risks (Simon, Houghton, \& Aquino, 2000). The rigor and tolerance for risk that is gained through the mitigation of uncertainties and datadriven planning brings resiliency to the entrepreneurial process (Bullough \& Renko, 2013; Bullough, Renko, \& Myatt, 2014). Additionally, the diversity of perspective and thought that comes through collaboration strengthens entrepreneurial strategies (Miles, Miles, \& Snow, 2006). Lastly, entrepreneurial strategies are enacted through a series of compelling stories designed to mobilize the resources (monetary, human, social) necessary to advance innovation and achieve impact (Garud, Schildt, \& Lant, 2014; Martens, Jennings, \& Jennings, 2007).

\section{Learning Setting}

The ELC that served as the backdrop for our study is delivered annually during a fourweek summer session at a research-intensive university located in the Southwestern United States. This project-based course was designed to intensively prepare first-generation college students with an advanced set of skills and knowledge in the areas of innovation and entrepreneurial strategy. The primary goal was to develop and/or improve the students' capacities to lead change regardless of environment or context. The four objectives that support this goal were: 1) Develop and pilot an entrepreneurial change strategy; 2) initiate innovation diffusion; 3) identify and assemble necessary resources; and 4) convey compelling entrepreneurial storylines to relevant stakeholder groups. Overall, the application of innovation and entrepreneurial strategy to the preparation and development of change agents that structure the course reflected our holistic definition of entrepreneurial leadership.

Project-based learning (PBL) has been shown to be highly effective in preparing students to be competitive within contemporary workforce environments that center on the rapid development and diffusion of innovation (Bell, 2010). This pedagogical strategy involves instructors guiding students through inquiries into topic-specific curiosities via projects that are commonly conducted within small teams (Prince \& Felder, 2007). PBL increases motivation for learning largely by affording students high levels of autonomy from topic selection through project completion (Bell, 2010; Blumenfeld, et al., 1991; Thomas, 2000), as well as by linking theory to practice in ways relevant to students' interests and passions (Fernandes, 2014; Lucas \& Goodman, 2015). Beyond mastering content knowledge and developing valuable soft skills (e.g., applied research, critical thinking), PBL enables students to become more aware of their individual and collective capacities to act in impactful and strategic ways. Specific to our study, the efficaciousness of PBL design has been described in the contexts of both entrepreneurship education (Cho \& Brown, 2013; Okuden \& Rzasa, 2006) and leadership education (Lucas, \& Goodman, 2015; Moore, Odom, \& Boyd, 2017). 
The design of the entrepreneurial leadership course that we examined centered on a project that involved students working in teams of two to three on the development and validation of an innovative solution and corresponding entrepreneurial strategy to a community, environmental, economic, and/or social problem of their choosing. The composition of the teams included memberships that crossed conventional disciplinary boundaries relevant to the programs of study being pursued by each member. Additionally, the project required the teams to immerse their emergent solutions and strategies in the communities that surrounded the university. In doing so, the students were expected to: 1) experience the process of engaging in entrepreneurial leadership within relevant environments, 2) observe and critically assess the assumptions influencing their solutions and strategies, 3) revise their solutions and strategies based on said observations and assessments, and 4) continually test the merits of their solutions through community-based experimentation.

While the course was restricted to students with "rising junior status," there were no limitations placed on the academic backgrounds and professional interests of students. The disciplinary backgrounds of the 62 students that were enrolled in the summer 2016 and 2017 courses (and thus participated in our study) included, but were not limited to education, the fine arts, engineering, humanities, and the social and the natural sciences. Both course offerings were delivered over four-week summer periods involving six days of eight-hour class sessions per week. Class activities included traditional lectures, field trips, and interactive discussions with guest lecturers with entrepreneurial expertise that spanned business, community development, environmental stewardship, and human services.

\section{Purpose and Research Objectives}

Our study examined the effectiveness of entrepreneurial leadership as an instructional focus for preparing collegiate students to be change agents regardless of their disciplinary interests and intended career paths. Specifically, we asked: "How, if at all, does entrepreneurial leadership education influence student proclivities to leading change?" To answer this question, we assessed changes in the self-reported proclivities of undergraduate students to the primary attributes of innovation and entrepreneurial strategy after having completed a project-based ELC. The following objectives guided our research:

1. Describe the change in perceived engagement in innovation following course completion.

2. Describe the change in perceived engagement in entrepreneurial strategy following course completion.

3. Describe the change in the proclivities to entrepreneurial leadership following course completion.

\section{Methods}

Research Design. We conducted descriptive-correlational survey research utilizing a retrospective pre- and post-measure pre-experimental design (Colosi \& Dunifon, 2006). Resembling Campbell and Stanley's (1963) one shot case study (with two post measures), the retrospective pre- and post-measure design is used to determine the impact of an educational intervention using a single intact group. This design was selected over a pre-test, post-test design 
with an educational intervention occurring between measures to minimize response shift bias. Response shift bias occurs in self-report measures where respondent's perception of the construct under assessment may change as a result of the educational intervention leading to an underreporting by the respondent of any real change occurring between pre-test and post-test (Howard \& Dailey, 1979). Whereas, a retrospective pre- and post-measure design allows respondents to recalibrate their perception allowing insight into their pre-intervention ability. In our study, the entrepreneurial leadership curriculum was the educational intervention.

Subject Selection. Two intact groups that occurred during the summers of $2016(n=32)$ and $2017(n=30)$ respectively were used to compose the sample $(n=62)$. The sample was composed of undergraduate students enrolled in a four-week intensive summer ELC. The course targeted students with an interest in enhancing their capacities to engage and lead in community development. There was a cross-disciplinary representation of major programs of study (i.e., agriculture, architecture, engineering, fine and performing arts, healthcare, humanities, management, public health, social and behavioral sciences) included in the sample.

Educational Intervention. The ELC involved a project-based curriculum and served as the educational intervention of our study. The curriculum was developed with the specific intent of preparing students with a leadership knowledge base and skill set in the areas of innovation and entrepreneurial strategy. Moreover, the curriculum was positioned in the context of community development rather than business creation. Derived from a combination of relevant curricula and literatures, the entrepreneurial leadership curriculum included commercial and social entrepreneurship, community development, entrepreneurial strategy, and innovation (Mars $\&$ Torres, 2014).

Two leadership constructs framed the development and delivery of the curriculum: innovation and entrepreneurial strategy. Innovation was defined as the initiation of novel products and/or processes with expected capacity to effectively address an economic, social, or technological challenge (Baumol, 2004, 2010). Five sub-constructs extracted from innovation theory underpinned the innovation constructs (adaptability, creativity, idea driven, interdisciplinary ideas, strategic intuition) (Chen, 2007; Gupta, et al., 2004; Kickul, et al., 2009; Miller \& Ireland, 2005). Entrepreneurial strategy was defined as the process of transforming innovative ideas into feasible interventions (Shane, 2003). Entrepreneurship theory guided the identification of five underpinning sub-constructs (collaboration, data driven, resiliency, risk tolerance, storytelling) (Bullough \& Renko, 2013; Bullough, et al., 2014; Garud, et al., 2014; Martens, et al., 2007; Miles, et al., 2006).

The course was taught by an entrepreneurship educator with more than a decade of experience teaching at the collegiate level. The course was delivered according to an intensive format that involved eight-hour daily sessions, five days per week over a four-week period. During this same period, students were required to participate in weekend field trips to offcampus sites that were illustrative of entrepreneurial leadership in the community development context. The format included structured lectures followed by activities and tasks that required individual and group application of content and skills. The instructor remained available to facilitate the individual and group activities. 
The primary deliverable of the curriculum was a team-based project that involved teams of two to three students with similar interests working together to identify, propose, validate, and refine an innovative solution and entrepreneurial strategy for addressing a community-based problem (Mars \& Torres, 2014). The problems students addressed were highly diverse to include, for example, environmental degradation. food insecurity, and women's health. Project tasks included, but were not limited to community- and market-based validation, primary and secondary research, proof of concepts, and written and oral communication to include public presentations of the final solutions and associated strategies.

Instrumentation. We developed the data collection instrument in consultation with the literature relevant to innovation and entrepreneurial strategy (Baumol, 2004, 2010; Bullough \& Renko, 2013; Bullough, et al., 2014; Chen, 2007; Garud, et al., 2014; Gupta, et al., 2004; Kickul, et al., 2009; Martens, et al., 2007; Miles, et al., 2006; Miller \& Ireland, 2005; Shane, 2003). The major constructs and associated sub-constructs of the questionnaire matched the aforesaid curricular constructs and associated sub-constructs. Specifically, the questionnaire was composed of two sections (i.e., innovation and entrepreneurial strategy) each with reflective- and post-measures. Each section consisted of 20 directly measured items to measure proclivity, where subjects were expected to respond using a five-point anchored, summated Likert-type scale with 1 (never) to 5 (always).

Measurement error was addressed by tending to issues of validity and reliability (Ary, Jacobs, Irvine, \& Walker, 2013). Validity was addressed using a panel of seven experts with backgrounds in entrepreneurship, entrepreneurship education, leadership education, and psychometrics. The questionnaire was assessed for content and construct validity. Based upon the critical review of the panel, the questionnaire was revised and subsequently pilot tested with subjects $(n=40)$ who approximated the characteristics of the study participants. A Cronbach's alpha was calculated to determine reliability estimates for the two major constructs and their associated sub-constructs. The alpha results of the pilot test were, innovation $=.93$, entrepreneurial strategy $=.92$. The innovation sub-construct alphas ranged from .60 to .87 , while the entrepreneurial strategy sub-construct alphas ranged from .71 to .90. We deemed all reliability estimates to be within acceptable levels for this study.

Data Collection and Analysis. Data were collected at the conclusion of each course (2016, 2017). Qualtrics was used as the web-based medium for distributing the questionnaire and thereby gathering the data. Students were invited, but not required to complete the questionnaire by the course instructor. The response rate for the 2016 intact group was $100 \%$, while the rate for the 2017 intact group was $87 \%$. Thus, the overall participant yield was a $94 \%$ response rate $(n=$ $58)$.

Data were analyzed using a statistical package (SPSS). Measures of central tendency and variability for each construct and sub-construct were reported. Cohen's $d$ was calculated for retrospective pre- and post-measures to determine standardized difference between the measures to discern effect size (Olejnika \& Igina, 2000, Cooper, Hedges, \& Valentine, 2009) of the entrepreneurial leadership curriculum. Cohen's (1988) guidelines were used to interpret the effect size of the findings where, $0.2=$ small effect, $0.5=$ medium effect, and $0.8=$ large effect. 
Data were combined for reporting purposes. Caution should be exercised to prevent extrapolation of the findings and conclusions, which are described next.

\section{Findings}

Our findings indicated an overall increase across the sample in entrepreneurial leadership proclivities following course completion (see Table 1). First, the composite score for innovation increased from a retrospective pre-course mean of $3.17(S D=.48)$ to a post-course mean of 4.04 $(S D=.31)$. Second, the composite score for entrepreneurial strategy increased from a retrospective pre- course mean of $3.42(S D=.42)$ to a post-course mean of $4.11(S D=.29)$. Figure 1 shows that students' retrospective pre-course completion entrepreneurial leadership proclivities were somewhat randomly scattered with proclivity measures being positioned in all four quadrants. The quadrants individually illustrate the following leadership categories: manager (low innovation, low entrepreneurial strategy), strategist (low innovation, high entrepreneurial strategy), innovator (high innovation, low entrepreneurial strategy), and entrepreneurial leader (high innovation, high entrepreneurial strategy). Figure 2 indicates that all the post-course completion proclivities were in the entrepreneurial leadership quadrant. Together, these two figures illustrate a notable shift in the entrepreneurial leadership proclivities of the students at the time of post-course completion.

Table 1.

Entrepreneurial Leadership Proclivities of Collegiate Students $(n=62)$

\begin{tabular}{lrrrrrrr}
\hline & \multicolumn{2}{c}{ Before } & & \multicolumn{2}{c}{ After } & \\
\cline { 2 - 3 } Construct $^{\mathrm{a}}$ & Mean & $S D$ & & Mean & SD & & Cohen's d $^{b}$ \\
\hline Innovation & 3.17 & 0.48 & & 4.04 & 0.31 & 3.04 \\
Entrepreneurial Strategy & 3.42 & 0.42 & & 4.11 & 0.29 & 1.91 \\
\hline
\end{tabular}

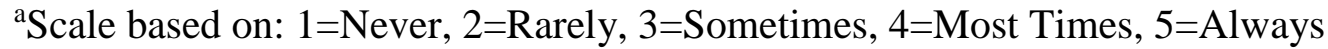

${ }^{\mathrm{b}}$ Cohen (1988) effect size conventions; 0.2=small, $0.5=$ medium, and $0.8=$ large 


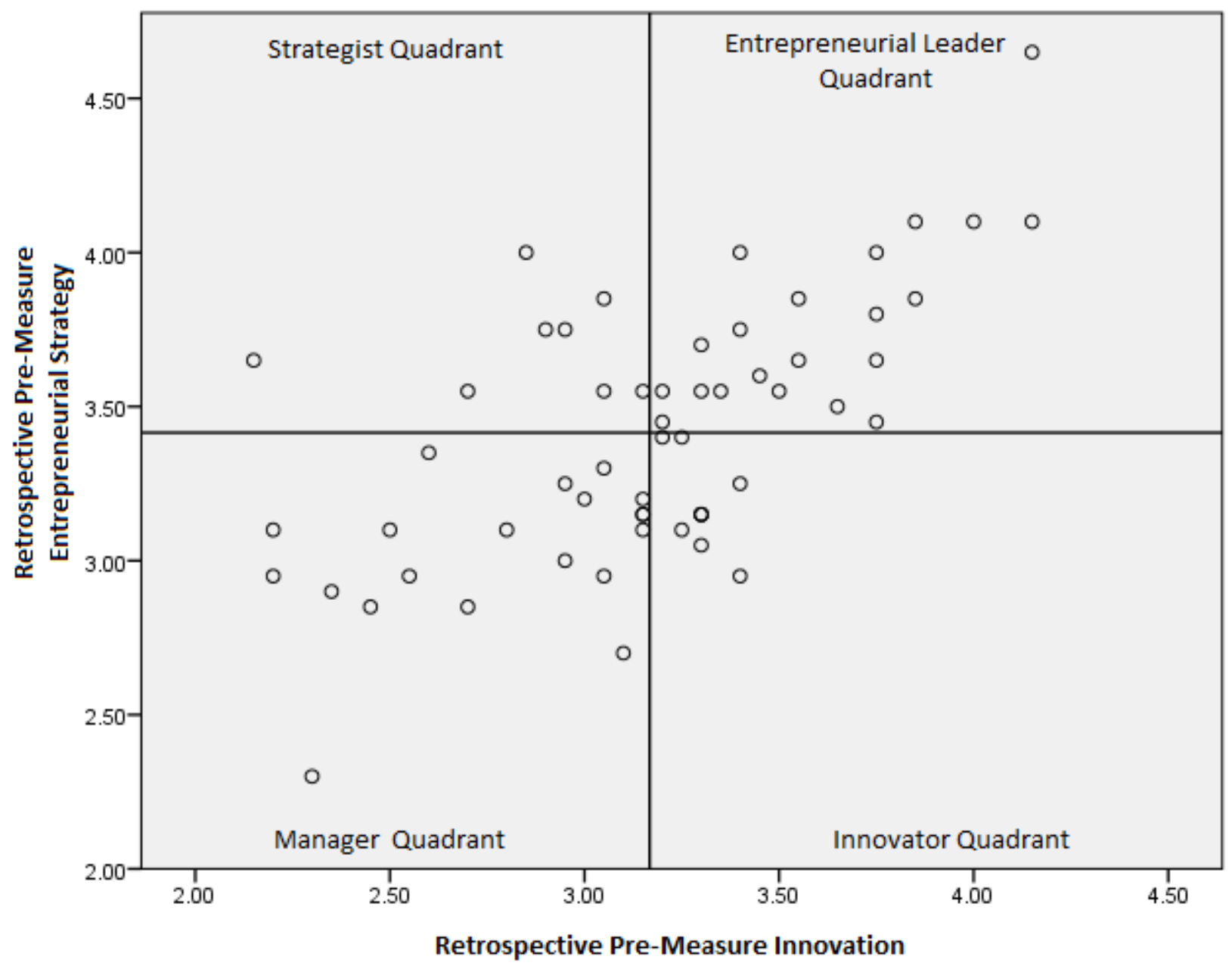

Figure 1. Retrospective Pre-Course Completion Entrepreneurial Leadership Proclivities $(n=62)$ 


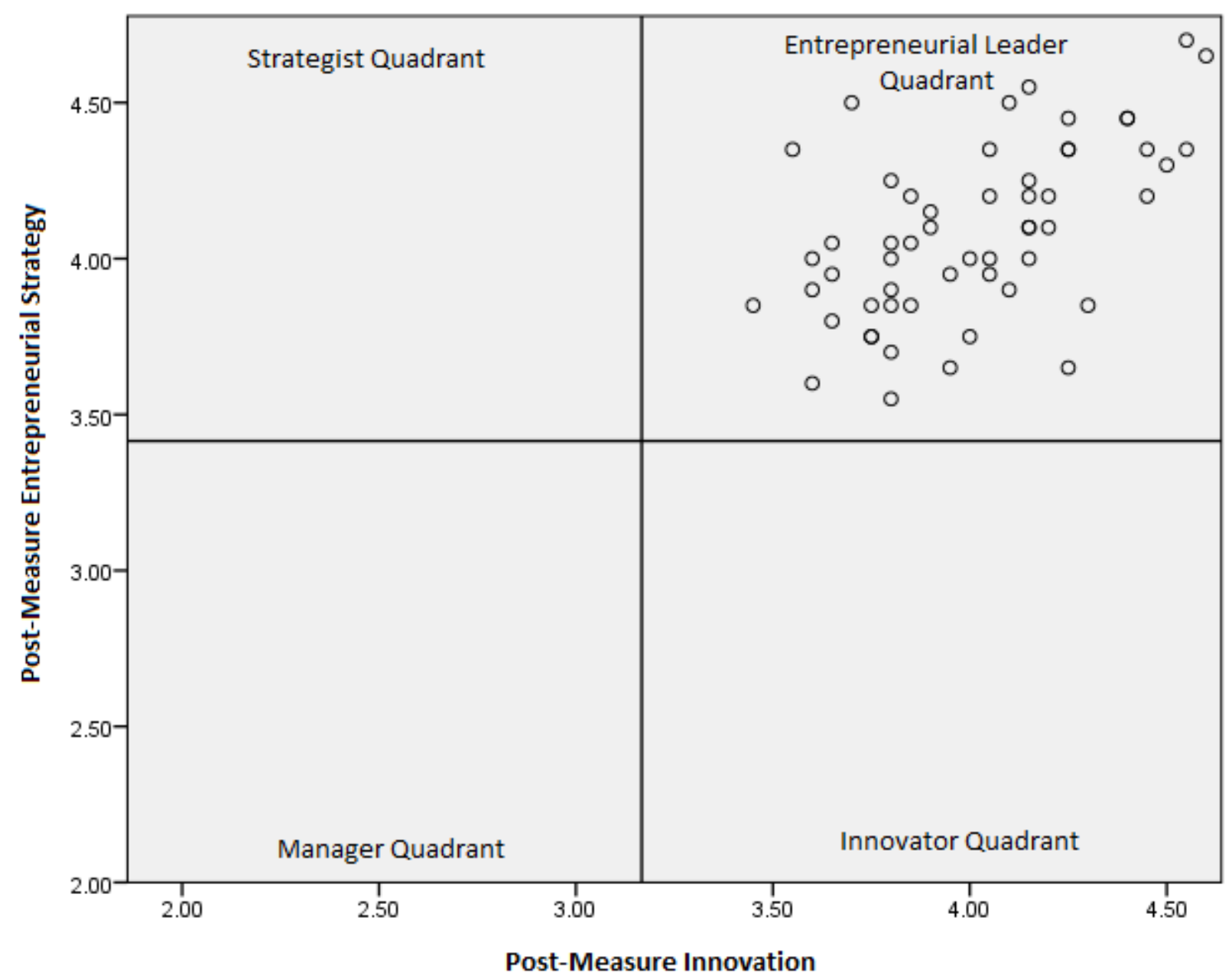

Figure 2. Post-Course Completion Entrepreneurial Leadership Proclivities $(n=62)$

The means for all sub-constructs that compose the innovation construct of entrepreneurial leadership proclivity showed retrospective pre- to post-curriculum increases (see Table 2). The effect size for these differences ranged from 1.03 to 2.01 as calculated using Cohen's $d$. The standardized differences between retrospective pre- and post-measures are viewed as large based on Cohen's (1988) guidelines for interpretation. The course experiences provided through the curriculum moved students' perceived behaviors relevant to all five innovation sub-constructs from "sometimes" to "most times" (see Table 2). The retrospective pre-/post-curriculum effect size for Interdisciplinary Idea Generation was most notable relative to the remaining four innovation sub-constructs. 
Table 2

Means, Standard Deviation, and Effect Size of Innovation Sub-Constructs $(n=62)$

\begin{tabular}{|c|c|c|c|c|c|}
\hline \multirow[b]{2}{*}{ Sub-Construct ${ }^{\mathrm{a}}$} & \multicolumn{2}{|c|}{ Before } & \multicolumn{2}{|c|}{ After } & \multirow[b]{2}{*}{ Cohen's $d^{b}$} \\
\hline & Mean & $S D$ & Mean & $S D$ & \\
\hline Interdisciplinary Idea Generation & 3.09 & 0.74 & 4.33 & 0.46 & 2.01 \\
\hline Adaptability & 3.40 & 0.56 & 4.32 & 0.41 & 1.87 \\
\hline Creative & 3.13 & 0.64 & 4.00 & 0.43 & 1.60 \\
\hline Strategic Intuition & 3.00 & 0.72 & 3.82 & 0.49 & 1.33 \\
\hline Idea Driven & 3.22 & 0.45 & 3.73 & 0.54 & 1.03 \\
\hline
\end{tabular}

a Scale based on: 1=Never, 2=Rarely, 3=Sometimes, 4=Most Times, 5=Always

${ }^{\mathrm{b}}$ Cohen (1988) effect size conventions; $0.2=$ small, $0.5=$ medium, and $0.8=$ large

The means for all sub-constructs that compose the entrepreneurial strategy construct of entrepreneurial leadership proclivity showed retrospective pre- to post-curriculum increases (see Table 3). The effect size for these differences ranged from 0.06 to 1.98 as calculated using Cohen's $d$. Retrospective pre- and post-measures were revealed as having, according to Cohen's (1988) guidelines for interpretation, a large effect size for three of the five entrepreneurial strategy sub-constructs (i.e., collaboration, storytelling, resiliency). The remaining two entrepreneurial strategy sub-constructs (i.e., data driven, risk tolerant) were found to have small effect size. Overall, the data indicated that students' perceived engaging in behaviors relevant to all five entrepreneurial strategy sub-constructs "most times" (see Table 3). Yet, retrospective preand post-curriculum measures showed little to medium effect size for the risk tolerant and data driven sub-constructs.

\section{Table 3}

Means, Standard Deviation, and Effect Size of Entrepreneurial Strategy Sub-Constructs $(n=$ 62)

\begin{tabular}{lcccccc}
\hline & \multicolumn{2}{c}{ Before } & & \multicolumn{2}{c}{ After } & \\
\cline { 2 - 3 } Sub-Construct & Mean & $S D$ & & Mean & $S D$ & Cohen's $d^{b}$ \\
\hline Collaboration & 3.13 & 0.77 & & 4.37 & 0.44 & 1.98 \\
Storytelling & 3.25 & 0.72 & & 4.19 & 0.41 & 1.60 \\
Resiliency & 3.62 & 0.64 & & 4.29 & 0.49 & 1.18 \\
Data Driven & 3.39 & 0.62 & & 3.73 & 0.54 & 0.58 \\
Risk Tolerant & 3.69 & 0.57 & & 3.66 & 0.46 & 0.06 \\
\hline
\end{tabular}

a Scale based on: 1=Never, 2=Rarely, 3=Sometimes, 4=Most Times, 5=Always

${ }^{\mathrm{b}}$ Cohen (1988) effect size conventions; $0.2=$ small, $0.5=$ medium, and $0.8=$ large

\section{Discussion}

Our primary intent has been to introduce entrepreneurial leadership as a holistic curricular approach to the preparation of effective change agents. Our analysis clearly indicated 
the ELC had an overall effect on the entrepreneurial leadership proclivities of the student participants. Specifically, the dispersion across the four leader types (manager, strategist, innovator, entrepreneurial leader) transformed from a relatively scattered retrospective precourse pattern to a post-course cluster with all participants being positioned somewhere within the entrepreneurial leader quadrant (see Figure 2). This retrospective pre- and post-course change in dispersion helps substantiate the promise of entrepreneurial leadership education as a model for better preparing college students to lead change within and across multiple contexts and settings (Davey, et al., 2016; Hackman, et al., 1999; Paxton \& Van Stralen, 2015).

The retrospective pre-/post-course effects on the students' entrepreneurial leadership proclivities largely aligned with the PBL instructional design and interdisciplinary composition of the course. For example, students were required to pursue their projects on teams of two to three, which ultimately resulted in collaboration between individuals with otherwise disparate academic interests and perspectives. This particular dynamic required both interdisciplinary idea generation (innovation sub-construct) and collaboration (entrepreneurial strategy sub-construct). The same dynamic also encouraged the students to craft and deliver entrepreneurial stories in a variety of ways in order to better appeal to diverse knowledge bases, experiences (academic, professional), and worldviews (entrepreneurial strategy sub-construct).

Similarly, the community-based aspect of the project challenged students to be adaptable to unexpected and uncontrollable conditions (innovation sub-construct) and in doing so recognize the importance of resiliency (entrepreneurial strategy sub-construct) when leading innovation and change. More specifically, the students drew on their individual and collective creativity and strategic intuition (innovation sub-constructs) to formulate their initial ideas into preliminary solutions. In turn, they were required to validate these early-stage solutions through community-based research and data-driven analysis (entrepreneurial strategy sub-construct). The teams were then required to revise their solutions to adapt to the insights revealed through their research and analysis (innovation and entrepreneurial strategy sub-constructs).

Interestingly, the course had no notable effect on the students' proclivities to risk tolerance (entrepreneurial strategy sub-construct). We do not interpret this finding as a limitation of the course curriculum or its PBL design. Instead, we consider the finding at the intersection of two of the entrepreneurial strategy sub-constructs: risk tolerance and data driven decision making. Specifically, the curriculum and its delivery was in part designed to counter the popular myth that entrepreneurs are heroic risk takers (Simon, et al., 2000). Instead, the students were encouraged to view entrepreneurial leaders and ultimately themselves as those who to the extent possible limit threats and uncertainties through data-driven analysis and decision making. In short, entrepreneurial leadership education should not promote careless risk taking. Instead, students should be empowered to strategically confront risk in thoughtful, responsible, and when possible evidence-based ways.

\section{Conclusions and Recommendations}

Entrepreneurial leadership is an underdeveloped curricular domain that warrants greater attention from leadership educators who have thus far limited the development of change agents to more mainstream models (e.g., servant and transformational leadership) (Davey, et al., 2016; 
Hackman, et al., 1999; Paxton \& Van Stralen, 2015). Indeed, entrepreneurial leadership remains a conceptual domain left confined to management education (Bagheri \& Pihie, 2011; Clarke, et al., 2006; Kuratko, 2007) as opposed to being treated as a holistic knowledge base and set of strategies relevant to the development of all change agents regardless of disciplinary background or professional field. Accordingly, we have asked, "How, if at all, does entrepreneurial leadership education influence student proclivities to leading change?" The interdisciplinary composition of the student included in our study coupled with the previously described retrospective pre-/post-course effect demystifies entrepreneurial leadership as a business-centric domain. Equally important, we have introduced entrepreneurial leadership as a cross-disciplinary domain within the broader pantheon of leadership education. This effort will strengthen collegiate leadership curriculum and instruction and enhance leadership educators in their efforts to equip students to become effective change agents.

Additionally, we have provided early evidence of the efficacy of delivering entrepreneurial leadership education through PBL designs. Management educators have identified PBL as an effective approach for teaching the skills and knowledge associated with innovation and entrepreneurship (Okudan \& Rzasa, 2006; Roomi \& Harrison, 2011). Here, we have further illustrated such understanding by showing the positive effects of a PBL design on the entrepreneurial leadership proclivities of students with diverse academic and professionals interests. Based on our findings, we contend that entrepreneurial leadership represents a conceptual approach with the promise of meeting the current call within the leadership education literature for new, more effective strategies for preparing learners to be innovative change agents (i.e., entrepreneurial leaders) (Paxton \& Van Stralen, 2015).

We are careful to note that the assessment of the entrepreneurial leadership skill and knowledge acquisition by the students is beyond the scope of our study. Instead, our data reveals the effects the course had on the proclivities of the students to entrepreneurial leadership. Recall the concept of proclivity reflects disposition and orientation rather than ability and action (Griffith, Noble, \& Chen, 2006; Matsuno, Mentzer, \& Ozsomer, 2002). In other words, we measured perceived rather than actual abilities. Thus, future studies that measure the skills and knowledge of students following the completion of project-based entrepreneurial leadership courses is warranted. Also, qualitative explorations of individual and team experiences and perspectives would likely produce deeper insights into how entrepreneurial leadership courses such as that which we featured here influence student proclivities to leading change. Lastly, we encourage the initiation and implementation of professional development models designed to enhance the innovation and entrepreneurial strategy skills and knowledge of leadership educators across the disciplinary landscape of the academy. 


\section{References}

Ary, D., Jacobs, L. C., Irvine, C. K. S., \& Walker, D. (2013). Introduction to research in education. Boston: Cengage Learning.

Austin, J., Stevenson, H., \& Wei-Skillern, J. (2006). Social and commercial entrepreneurship: Same, different, or both? Entrepreneurship Theory \& Practice 30(1), 1-22. doi: 10.1111/j.1540-6520.2006.00107.x

Bae, T.J., Qian, S., Miao, C., \& Fiet, J.O. (2014). The relationship between entrepreneurship education and entrepreneurial intentions: A meta-analytical review. Entrepreneurship Theory \& Practice, 38(2), 217-254. doi: 10.1111/etap.12095

Bagheri, A., \& Pihie, Z.A.L. (2011). Entrepreneurial leadership: Towards a model for learning and development. Human Resource Development International, 14(4), 447-463. doi: 10.1080/13678868.2011.601594

Baumol, W.J. (2004). Education for innovation: Entrepreneurial breakthroughs vs. corporate incremental improvements. Working Paper 10578, National Bureau of Economic Research.

Baumol, W.J. (2010). The microtheory of innovative entrepreneurship. Princeton, NJ: Princeton University Press.

Bell, S. (2010). Project-based learning for the $21^{\text {st }}$ century: Skills for the future. The Clearning House: A Journal of Educational Strategies, Issues and Ideas, 83(2), 39-43. doi: 1080/00098650903505415

Blumenfeld, P.C., Soloway, E., Marx, R., Krajcik, J., Guzdial, M., \& Palincsar, A. (1991). Motivating project-based learning: Sustaining the doing, supporting the learning. Educational Psychologist, 26(3\&4), 369-398. doi: 10.1080/00461520.1991.9653139

Borasi, R., \& Finnigan, K. (2010). Entrepreneurial attitudes and behaviors that can help prepare successful change-agents in education. The New Educator, 6(1), 1-29. doi: 10.1080/1547688.2010.10399586

Boyles, T. (2012). $21^{\text {st }}$ century knowledge, skills, and abilities and entrepreneurial competencies: A model for undergraduate entrepreneurship education. Journal of Entrepreneurship Education, 15, 41-55.

Bullough, A., \& Renko, M. (2013). Entrepreneurial resilience during challenging times. Business Horizons, 56(3), 343-350. doi: 10.1016/j.bushor.2013.01.001

Bullough, A., Renko, M., \& Myatt, T. (2014). Danger zone entrepreneurs: The importance of resilience and self-efficacy for entrepreneurial intentions. Entrepreneurship Theory \& Practice, 38(3), 473-499. doi: 10.1111/etap.12006 
Campbell, D.T., \& Stanley, J.C. (1963). Experimental and quasi-experimental designs for research. In N.L. Gage (Ed.), Handbook on Research on Teaching (pp.171-246). Chicago: Rand McNally.

Chen, M. (2007). Entrepreneurial leadership and new ventures: Creativity in entrepreneurial teams. Entrepreneurial Leadership and New Ventures, 16(3), 239-249. doi: 10.1111/j.1467-8691.2007.00439.x

Cho, Y., \& Brown, C. (2013). Project-based learning in education: Integrating business needs and student learning. European Journal of Training and Development, 37(8), 744-765. doi: 10.1108/EJTD-01-2013-0006.

Clarke, J., Thorpe, R., Anderson, L., \& Gold, J. (2006). It's all action, it's all learning: Action learning in SMEs. Journal of European Industrial Training, 30(6), 441-455. doi: $10.1108 / 03090590610688825$

Cogliser, C.C., \& Brigham, K.H. (2004). The intersection of leadership and entrepreneurship: Mutual lessons to be learned. The Leadership Quarterly, 15(6), 771-799. doi: 10.1016/j.leaqua.2004.09.004

Cohen, J. (1988). Statistical power analysis of the behavioral sciences. (2nd ed.). New York: Academic Press.

Colosi, L., \& Dunifon, R. (2006). What's the difference? "Post then pre” \& "pre-then post." Cornell University: Cornell Cooperative Extension.

Cooper, H., Hedges, L.V, \& Valentine, J. C. (2009). The Handbook of Research Synthesis and Meta-Analysis. Russel Sage Foundation, 632

Davey, T., Hannon, P., \& Penaluna, A. (2016). Entrepreneurship education and the role of universities in entrepreneurship: Introduction to the special issue. Industry and Higher Education, 30(2), 171-182. doi: 10.1177/0950422216656699

DeTienne, D.R., \& Chandler, G.N. (2004). Opportunity identification and its role in the entrepreneurial classroom: A pedagogical approach and empirical test. Academy of Management Learning \& Education, 3(3), 242-257. doi: 10.5465/AMLE.2004.14242103

Duval-Couetil, N. (2013). Assessing the impact of entrepreneurship education programs: Challenges and approaches. Journal of Small Business Management, 51(3), 394-409. doi: $10.1111 /$ jsbm. 12024

Eisenbach, R., Watson, K., \& Pillai, R. (1999). Transformational leadership in the context of organizational change. Journal of Organizational Change Management, 12(2), 80-88. doi: 10.1108/09534819910263631 
Engelen, A., Gupta, V., Strenger, L., \& Brettel, M. (2015). Entrepreneurial orientation, firm performance, and the moderating role of transformational leadership behaviors. Journal of Management, 41(4), 1069-1097. doi: 10.1177/0149206312455244

Fernald, L.W., Jr., Solomon, G.T., \& Tarabishy, A. (2005). A new paradigm: Entrepreneurial leadership. Southern Business Review, 30(2), 1-10.

Fernandes, S.R.G. (2014). Preparing graduates for professional practice: Findings from a case study of project-based learning (PBL). Procedia - Social and Behavioral Science, 139, 219-226. doi: 10.1016/j.sbspro.2014.08.064

Garud, R., Schildt, H.A., \& Lant, T.K. (2014). Entrepreneurial storytelling, future expectations, and the paradox of legitimacy. Organization Science, 25(5), 1479-1492. doi:

10.1287/orsc.2014.0915

Griffith, D.A., Noble, S.M., \& Chen, Q. (2006). The performance implications of entrepreneurial proclivity: A dynamic capabilities approach. Journal of Retailing, 82(1), 51-62. doi: 10.1016/j.jretai.2005.11.007

Gumusluoglu, L., \& Ilsev, A. (2009). Transformational leadership, creativity, and organizational innovation. Journal of Business Research, 62, 461-473. doi:

10.1016/j.jbusres.2007.07.032

Gupta, V., MacMillan, I.C., \& Surie, G. (2004). Entrepreneurial leadership: Developing and measuring a cross-cultural construct. Journal of Business Venturing, 19, 241-260. doi: 10.106/S0883-9026(03)00040-5

Hackman, M.Z., Olive, T.E., Guzman, N., \& Burman, D. (1999). Ethical considerations in the development of the interdisciplinary leadership studies program. Journal of Leadership \& Organizational Studies, 6(1-2), 36-48. doi: 10.1177/1079199900600103

Heinonen, J., \& Poikkijoki, S.A. (2006). An entrepreneurial-directed approach to entrepreneurship education: Mission impossible? Journal of Management Development, 25(1), 80-94. doi: 10.1108/026217106106379

Henry, C., Hill, F., \& Leitch, C. (2005). Entrepreneurship education and training: Can entrepreneurship be taught? Part 1. Education + Training, 47(2), 98-111. doi: $10.1108 / 00400910510586524$

Herold, D.M., Fedor, D.B., \& Cladwell, S. (2008). The effects of transformational and change leadership on employees' commitment to a change: A multilevel study. Journal of Applied Psychology, 93(2), 346-357. DOI: 10.1037/0021-9010-93.2.346

Howard, G.S., \& Dailey, P.R (1979). Response-shift bias: A source of contamination of selfreport measures. Journal of Applied Psychology, 64(2), 144-150. doi: 10.1037/0021 9010.64.2.144 
Katz, J.A. (2003). The chronology and intellectual trajectory of American entrepreneurship education: 1876-1999. Journal of Business Venturing, 18(2), 283-300. doi: 10.1016/S0883-9026(02)00098-8

Kickul, J., Gundry, L.K., Barbosa, S.D., \& Whitcanack, L. (2009). Intuition versus analysis? Testing differential models of cognitive style on entrepreneurial self-efficacy and the new venture creation process. Entrepreneurship Theory and Practice, 33(2), 439-453. doi: $10.1111 / \mathrm{j} / 1540-6520.2009 .00298 . x$

Kuratko, D.F. (2005). The emergence of entrepreneurship education: Development, trends, and challenges. Entrepreneurship Theory and Practice, 29(5), 577-598. DOI: 10.1111/j.1540 6520.2005.00099.x

Kuratko, D. (2007). Entrepreneurial leadership in the $21^{\text {st }}$ century. Journal of Leadership \& Organizational Studies, 13(4), 1-11. doi: 10.1177/10717919070130040201

Lamm, A.J., Lamm, K.W., Rodriguez, M.T., \& Owens, C.T. (2016). Examining leadership style influence on engagement in a national change process: Implications for leadership education. Journal of Leadership Education, 15(4), 1-14. doi: 1012806/V15/14/R1

Leitch, C.M., McMullen, C., \& Harrison, R.T. (2013). The development of entrepreneurial leadership: The role of human, social, and institutional capital. British Journal of Management, 24(3), 347-366. doi: 10.1111/j.1467-8551.2011.00808.x

Leitch, C.M., \& Volery, T. (2017). Entrepreneurial leadership: Insights and directions. International Small Business Journal, 35(2), 147-156. doi: 10.1177/0266242616681397

Lucas, N., \& Goodman, F.R. (2015). Well-being, leadership, and positive organizational scholarship: A case study of project-based learning in higher education. Journal of Leadership Education, 14(4), 138-152. doi: 1012806/V14/I4/T2Special2015

MacKenzie, S., Podsakoff, P.M., \& Rich, G.A. (2001). Transformational and transactional leadership and salesperson performance. Academy of Marketing Science Journal, 29(2), 115-134. doi: 10.1177/03079459994506

Mars, M.M., \& Rhoades, G. (2012). Socially-oriented student entrepreneurship: A study of student change agency in the academic capitalism context. The Journal of Higher Education, 83(3), 435-459. doi: 10.1080/00221546.2012.11777251

Mars, M.M., \& Torres, R.M. (2014). Enhancing agricultural leadership education through the inclusion of entrepreneurial principles and practices. NACTA Journal, 58(4), 284-289.

Martens, M.L., Jennings, J.E., \& Jennings, P.D. (2007). Do the stories they tell get them the money they need? The role of entrepreneurial narratives in resource acquisition. Academy of Management Journal, 50(5), 1107-1132. doi: 10.5465/AMJ.2007.27169488 
Martin, B.C., McNally, J.J., \& Kay, M.J. (2013). Examining the formation of human capital in entrepreneurship: A meta-analysis of entrepreneurship outcomes. Journal of Business Venturing, 28(2), 211-224. doi: 10.1016/j.busvent.2012.03.002

Maton, K.I. (2008). Empowering community settings: Agents of individual development, community betterment, and positive social change. American Journal of Community Psychology, 41, 4-21. doi: 10.1007/s10464-007-9148-6

Matsuno, K., Mentzer, J.T., \& Ozsomer, A. (2002). The effects of entrepreneurial proclivity and market orientation on business performance. Journal of Marketing, 66(3), 18-32. doi: 10.1059/jmkg.66.3.18.18507

McGrath, R.G., \& MacMillan, I.C. (2000). The entrepreneurial mindset. Boston: Harvard Business School Press.

Miles, R.E., Miles, G., \& Snow, C.C. (2006). Collaborative entrepreneurship: A business model for continuous innovation. Organizational Dynamics, 35, 1-11.

Miller, C.C., \& Ireland, R.D. (2005). Intuition in strategic decision making: Friend or foe in the fast-paced $21^{\text {st }}$ century. Academy of Management Perspectives, 19(1), 19-30. doi: 10.5465/AME.2005.15841948

Miller, T.L., Wesley, II, C.L., \& Williams, D.E. (2012). Education the minds of caring hearts: Comparing the views of practitioners and educators on the importance of social entrepreneurship competencies. Academy of Management Learning \& Education, 11(3), 349-370. doi: 10.5465/amle2011.0017

Moore, L.L., Odom, S.F., \& Boyd, B.L. (2017). The team leadership summit: Culminating the leadership experience. Journal of Leadership Education, 16(3), 1-8. doi: 1012806/V16/I3/A1

Okuden, G.E., \& Rzasa, S.E. (2006). A project-based approach to entrepreneurial education. Technovation, 26(2), 195-210. doi: 10.1016/j.technovation.2004.10.012

Olejnika, S., \& lgina, J. (2000). Measures of effect size for comparative studies: Applications, interpretations, and limitations. Contemporary Educational Psychology, 25(3), 241-286. doi: $10.1006 /$ ceps. 2000.1040

Oosterbeek, H., van Praag, M., \& Ijsselstein, A. (2010). The impact of entrepreneurship education on entrepreneurship skills and motivation. European Economic Review, 54(3), 442-454. doi: 10.1016/j.euroecorev.2009.08.002

Pache, A.C., \& Chowdhury, I. (2012). Social entrepreneurs as institutionally embedded entrepreneurs: Toward a new model of social entrepreneurship. Academy of Management Learning \& Education, 11(3), 494-510. doi: 10.5465/amle.2011.0019 
Paxton, D., \& Van Stralen, S. (2015). Developing collaborative and innovative leadership: Practices for fostering a new mindset. Journal of Leadership Education, 14(4), 11-25. doi: 1012806/V14/14/11

Pittaway, L., \& Cope, J. (2007). Entrepreneurship education: A systematic review of the evidence. International Small Business Journal, 25(5), 479-510. doi: $10.1177 / 0266242607080656$

Powell, W.W., \& Snellman, K. (2004). The knowledge economy. Annual Review of Sociology, 30, 199-220. doi: 10.1146/annurev.soc.29.010202.100037

Prince, M., \& Felder, R. (2007). The many faces of inductive teaching and learning. Journal of College Science Teaching, 36(5), 14-20.

Roomi, M.A., \& Harrison, P. (2011). Entrepreneurial leadership: What is it and how should it be taught? International Review of Entrepreneurship, 9(3), 1-44.

Sanchez, J.C. (2013). The impact of an entrepreneurship education program on entrepreneurial competencies and intention. Journal of Small Business Management, 51(3), 447-465. doi: $10.1111 /$ jsbm. 12025 .

Santos, F.M. (2012). A positive theory of social entrepreneurship. Journal of Business Ethics, 111(3), 335-351. doi: 10.1007/s10551-012-1413-4

Shane, S.A. (2003). A general theory of entrepreneurship: The individual-opportunity nexus. Northampton, MA: Elgar.

Simon, M., Houghton, S.M., \& Aquino, K. (2000). Cognitive biases, risk perception, and venture formation: How individuals decide to start companies. Journal of Business Venturing, 15(2), 113-134. doi: 10.1016/S0883-9026(98)00003-2

Surie, G., \& Ashely, A. (2008). Integrating pragmatism and ethics in entrepreneurial leadership for sustainable value creation. Journal of Business Ethics, 81(1), 235-246. doi:

$10.1007 / \mathrm{s} 105551-007-9491-4$

Thomas, J.W. (2000). A review of research on project-based learning. San Rafael, CA: Autodesk Foundation.

Tracey, P., \& Phillips, N. (2007). The distinctive challenge of educating social entrepreneurs: A postscript and rejoinder to the special issue on entrepreneurship education. Academy of Management Learning \& Education, 6(2), 264-271. doi: 10.5465/AMLE.2007.25223465

Vecchio, R.P. (2003). Entrepreneurship and leadership: Common trends and common threads. Human Resource Management Review, 13(2), 303-327. doi:

10.1016/S10534822(03)00019-6 
Wagner, T. (2012). Creating innovators: The making of young people who will change the world. New York: Scribner.

Westover, J.H. (2010). Managing organizational change: Change agent strategies and techniques to successfully managing the dynamics of stability and change in organizations.

International Journal of Management and Innovation, 2(1), 45-50.

Zhao, H., Seibert, S.E., \& Hillis, G.E. (2005). The mediating role of self-efficacy in the development of entrepreneurial intentions. Journal of Applied Psychology, 90(6), 1265 1272. doi: 10.1037/0021-9010.90.6.1265

Zhou, L. (2007). The effects of entrepreneurial proclivity and foreign market knowledge on early internalization. Journal of World Business, 42(3), 281-293. doi: 10.1016/j.jwb.2007.04.009

Zhou, L., Barnes, B., \& Lu, Y. (2010). Entrepreneurial proclivity, capability upgrading and performance advantage of newness among international new ventures. Journal of International Business Studies, 41(5), 882-905. doi: 10.1057/jibs.2009.87

\section{Author Biographies}

Matthew M. Mars (mmars@email.arizona.edu) is Assistant Professor of Leadership and Innovation and Director of Graduate Studies in the Department of Agricultural Education at the University of Arizona.

Robert M. Torres (rtorres1@email.arizona.edu) is Professor of Agricultural Education and Head in the Department of Agricultural Education at the University of Arizona. 